\title{
Estimation of Determinants of Total Factor Productivity of Millets in Karnataka: An Application of Parametric Approach
}

\author{
T.M. Dinesh ${ }^{1 *}$, K. Suhasini ${ }^{2}$, B. Dayakar Rao $^{3}$, I.S. Rao ${ }^{4}$ and D. Srinivasa Chary ${ }^{5}$ \\ ${ }^{1}$ Department of Agricultural Economics, College of Agriculture, PJTSAU, Hyderabad \\ ${ }^{2}$ Department of Agricultural Economics, College of Agriculture, PJTSAU, Hyderabad \\ ${ }^{3}$ Indian Institute of Millet Research, Hyderabad \\ ${ }^{4}$ Department of Agricultural Extension, Extension Education Institute, Hyderabad \\ ${ }^{5}$ Department of Statistics \& Mathematics, College of Agriculture, PJTSAU, Hyderabad \\ *Corresponding author
}

\begin{abstract}
A B S T R A C T
Keywords

Total factor productivity, Parametric approach

Article Info

Accepted:

15 June 2019

Available Online:

10 July 2019

Total factor productivity indicates the contribution of noninputs to the growth of agricultural productivity. In this study, the estimation of total factor productivity of millets in Karnataka and returns to investment in research in Karnataka is attempted. For the study, the time series data on the cost of cultivation was collected from farm management reports, published by Directorate of Agriculture, Government of Karnataka. The Tornqvist Theil index of TFP is used for measuring TFP growth. Regression analysis was employed to identify sources of TFP growth. The result reveals that the total factor productivity index of jowar grew at an average of 1.18 and ragi at 0.92 percent per annum. Government expenditure on agriculture research and extension, the ratio of $\mathrm{N}$ to $\mathrm{P}$ and cropping intensity are the factors significantly contributed to TFP growth in jowar and ragi in Karnataka. The total factor productivity in jowar and ragi registered marginal growth in Karnataka. Hence, the Government should allocate substantial funds to public research for productivity improvement and awareness creation on the usage of the $\mathrm{N}$ to $\mathrm{P}$ ratio would increase the productivity growth of millets in Karnataka.
\end{abstract}

\section{Introduction}

Millets are rain fed crops and are grown in regions with low rainfall and thus resume greater importance for sustained agriculture and food security. These crops grown in the semiarid tropics of Asia and Africa (especially in India, Mali, Nigeria, and Niger), with $97 \%$ of millet production in developing countries (McDonough et al.,
2000). Jowar, bajra and ragi, which grouped as millets, are grown in marginal lands, especially in India, since they ae grown in rain fed conditions, fertilizer and pesticide consumption follow the rainfall pattern. Majority of millet crops are native of India and are popularly known as Nutri-cereals as they provide most of the nutrients required for normal functioning of human body. Further, the nutritional value of these crops offers 
much scope for development of value-added products in new health conscious consumer segments (Yadav, et al., 2011). These crops are the only alternative choice as they come up in extremely unsuitable areas and perform well-sustaining hardships of climate change. However, the last few decades saw these crops lose area on account of declining demand due to change in food habits and due attention has been given to cereals and commercial crops cultivation in India, that resulted in a drop in real prices vis-a-vis other competing crops leading to erosion in the relative profitability of these crops. As a result, major millets acreage in this country has gradually decreased at a compound annual growth rate of -1.6 percent, production at a rate of -0.3 percent and productivity increased marginally i.e. 1.6 percent (Directorate of Economics and Statistics, GOI, 2015).Karnataka witnessed an increase in the production post green revolution period due to introduction of high yielding varieties and improved technologies. The increased performance of the agriculture sector was attributed to the increased investment in agricultural research and education. In the present context of declining trend in production of millets, there is a need to revise the factors other than primary inputs that contribute to the millets production of the state, and find out the corners where necessary steps should be taken

\section{Materials and Methods}

The estimation of total factor productivity for Karnataka was based on data compiled under the Comprehensive Scheme for the Study of Cost of Cultivation of Principal Crops in India. The time period considered was 197172 to 2015-16. The linear approximation was considered in a year where data was not available. Seven major inputs considered are seed $(\mathrm{Kg})$, fertilizer (Kg), manure (Qtls), human labour (Hrs), animal labour (Hrs), machine labour(Hrs) and irrigation(Hrs). The variables machine labour and irrigation are available only in value terms. Machines typically consist of tractors which run on diesel. Irrigation is usually carried out through diesel or electric pump-sets. Therefore, an index was constructed for both machine labour and irrigation expenditure by deflating the variables by the Fuel and Light index available from the Consumer Price Index Numbers for Agricultural and Rural Labourers in India. The total factor productivity (TFP) being the ratio of growth of output to all the factors involved in the production process, a preferred concept is being followed in this study. To estimate TFP change, we have considered two different methods, viz. Törnqvist-Theil index method and Malmquist index method. Both methods have their own merits and demerits. However, the Törnqvist-Theil index method imposes certain theoretical restrictions. The time-series data on variables like average rainfall in the state, percent irrigated area, cropping intensity, the ratio of nitrogenous fertilizers to phosphorous fertilizers and rural literacy were collected from various statistical yearbooks published by the Directorate of Economics and Statistics, Government of Karnataka. Data on government expenditure on agricultural research and education was collected from the office of the Accounts General, Government of Karnataka.

The Divisia-Tornqvist index or translog index was used in this study for computing the total output, total input, and TFP indices.

The total output, total input and TFP indices have been calculated as under:

Total Output Index (TOI)

$=\pi\left(\frac{Q_{j t}}{Q j t-1}\right)^{(R j t+R j t-1)^{\frac{1}{2}}}=A_{t}$

Total Input Index (TII) 
$\frac{T I I_{t}}{T I I_{t-1}}=\pi\left(\left(\frac{X_{i t}}{X_{i t-1}}\right)^{\left(S_{i t}+S_{i t-1}\right)^{1 / 2}}\right)=B_{t}$

Where,

$R_{j t}$ is the share of $j^{\text {th }}$ crop output in total revenue in year $t$,

$\mathrm{Q}_{\mathrm{jt}}$ is the output of $\mathrm{j}^{\text {th }}$ crop in year $\mathrm{t}$,

$S_{\text {it }}$ is the share of input $i^{\text {th }}$ the total input cost in year $\mathrm{t}$, and

$\mathrm{X}_{\mathrm{it}}$ is the quantity of input $\mathrm{i}$ in year $\mathrm{t}$.

Total Output Index (TOI) and Total Input Index (TII) for the year $t$ computed from

Equations 3.4 and 3.5 as follows:

$$
\begin{aligned}
& \text { TOI }(t)=A 1 \text { A } 2 \ldots \ldots \ldots . A t \\
& \text { TII }(t)=B 1 \text { B2 } \ldots \ldots \ldots . . . B t
\end{aligned}
$$

The Total Factor Productivity (TFP) index is given as

$$
\begin{aligned}
& \text { TFPt }=\{\text { TOI }(\mathrm{t}) / \text { TII }(\mathrm{t})\}= \\
& \left.\mathrm{R}_{j t}+R_{j t-1}\right) \ln \left(\frac{Q_{j t}}{Q_{j t-1}}\right)-\frac{1}{2} \sum_{i}\left(S_{i t}+S_{i t-1}\right) \ln \left(\frac{x_{i t}}{x_{i t-1}}\right)
\end{aligned}
$$

For constructing the TFP index, the chain index is preferred to fixed base index (Coelli et al., 2005). Chain index combines annual changes in productivity to measure changes in productivity over a period of time. In other words, let $I(t+1, t)$ be an index for the period $t+1$ with the base period $t$. This index is applied to time series $\mathrm{t}=0$ to $\mathrm{T}$. A comparison between period $t$ and fixed base 0 is made by following chain indexing of successive periods.

$\mathrm{I}(0, \mathrm{t})=\mathrm{I}(0,1) \times \mathrm{I}(1,2) \times \mathrm{I}(2,3) \times \ldots \ldots \ldots . . . \mathrm{x}$
$\mathrm{I}(\mathrm{t}-1, \mathrm{t})$

Multiple regression analysis was carried out in order to detect the main factors that were influencing the total factor productivity (TFP) growth in Telangana agriculture. For this purpose, the crop wise indices of TFP in Telangana state was regressed on various identified variables that affect the TFP growth. Natural logarithm of all the variables including the TFP was taken for the regression analysis except those variables represented as ratios and percentages. The basic model for this purpose was as follows,

$\ln \left(\mathrm{TFP}_{\text {crop }}\right)=\mathrm{f}\{\ln ($ Government expenditure on agricultural research and education per hectare of cultivated land), ln (Average rainfall in the state in millimetre), In (transport infrastructure=road density, railway density/100sqkm), ln (Rural literacy in percentage), ln (Cropping intensity), Percent irrigated area, Percent canal irrigated area, $\mathrm{ln}$ (Ratio of nitrogenous fertilisers to phosphorous fertilisers) $\}$

\section{Results and Discussion}

\section{Tornquist total factor productivity indices of jowar}

The Tornqvist total output index (TOI), total input index (TII) and total factor productivity index (TFP) of jowar in the state of Karnataka were estimated for a period of 45 years from 1971 to 2015-16 and sub-periods considered were period I (1971-1984), period II (19851994), period III (1995-2004), period IV(2005-2015) and pooled samples have been presented for comparison(1971-2015). These indices were transitive and relative to the first observation of the study. The results have been presented in Table 1. The three indices of TOI, TII and TFP Tornqvist index (T) and Malmquist TFP (M) for the state Karnataka are presented graphically in Figure 1. The 
values of TOI started to increase from 19711984 to 1985-1994 period and decreased in 1995 -2004 period i.e., after the liberalization of the economy, it may be due to the liberalization of the economy did not bring much investment into the coarse cereals and much importance has been laid to the commercial crops. The average value of TOI was 1.227 and growing annually at a rate of 0.352.TII started to increase from 1971-84 to the 1995-2004 period and decreased in the 2005-2015 period and registered highest in the 1995-2004 period. The average value of TII was 1.037 and growing annually at the rate of 0.281 significant at 5 percent level. Similar to the TOI, TFP growth increased up to 1994 and decreased in a $1995-2004$ period later during the Period IV the same has been picked due to the realization of importance by government and acceptance of HYV and hybrids might be contributed due to increased growth of TOI over TII and registered above 1 mark (1.272). The average value was 1.188 and growing annually at a rate of 0.07 and non-significant.

Further, the determinants of TFP in jowarhas been worked out by using log-linear functional analysis and results were presented in Table 2. The index of the total factor productivity (TFP) of jowar in Karnataka state was regressed with the selected variables to find out the main factors that were influencing the productivity growth of the crop in the state. After the necessary check formulticollinearity among the independent variables in the model, the key factors identified to be influencing the

TFP growth of jowar were government expenditure on agricultural research and education (per ha) (0.16), cropping intensity and percentage canal irrigated area. The coefficient of determination of the model was 57 percent. The value of the $\mathrm{D}-\mathrm{W}$ statistics (2.51) was non-significant implying that there was no problem of autocorrelation among the residuals of the regression model. There was also no problem of heteroskedasticity in the selected regression model. Since government expenditure on agricultural research and education (per ha) (0.16) has a significant influence on TFP, research investment should be made in value addition at farm level, processing technologies should be made available to the farmers. IIMR-Hyderabad and DST has taken the joint initiative in this direction to develop and made available processing technologies to the farmers.

\section{Tornqvist total factor productivity indices of ragi}

The output, input and TFP indices of ragi (finger millet) crop are presented in Table 3. From Table 3 it was observed that the TFP for ragi (finger millet) increased from 0.775 in the 1995-2004 period to 1.116 in the 20052015 period. From Figure 2, it can be observed that the TFP fell to 0.4 in 1994 and 0.8 in 2002 due to drought during that period. The highest TFP index was observed in 201314 (1.57). The average TFP index for 32 years was 0.921 and CAGR was 1.197 significant at 5 percent level. The output index of ragi (finger millet) increased from 0.94 in the 1995-2004 period to 1.075 in the 2005-2015 period. The output growth fell to 0.65 in 2002-03, the highest output index was observed in 1984 (1.4). The average output index for 32 years was 1.026 and CAGR was -0.095. In the case of the input index, there were heavy fluctuations, decreasing from 1.30 in the 1995-2004 period to 0.97 in the 20052015 period. The average input index of ragi (finger millet) was 1.18 and CAGR was -1.12 and non-significant for 32 years. Which implies that much attention was not given by researchers and policy makers for ragi crop improvement. Whereas in the case of Malmquist TFP (M) index TFP increased from 0.988 in $1984-94$ to 1.239 in the 2005 - 
2015 period. From the Figure 2 it can be observed that highest TFP was observed in 2013-14 (2.057) and lowest TFP growth was observed in 2014-15 (0.18) and TFP growth was observed to growing at 0.13 percent annually.

The growth rate in TFP was analyzed to quantify the contributions of various factors to TFP growth such as research expenditure, rural literacy, annual rainfall, road density, cropping intensity, $\mathrm{N}$ to $\mathrm{P}$ ratio on TFP of ragi (Table 3). The results indicate that public research (0.16) and $\mathrm{N}$ to $\mathrm{P}$ ratio (- 0.606) significantly contributed to TFP growth in ragi (finger millet). The rainfall is a crucial determinant of TFP in ragi (finger millet). The ratio of nitrogen to phosphorus nutrients $(-0.606)$ was taken as a proxy for the balanced use of fertilizer. This coefficient was negative and significant. The estimated $\mathrm{R}$ square value was 0.69 indicating that 69 percent of the variation in TFP explained by the factors included in the model and D-W (1.94) value was statistically non -significant indicating a no autocorrelation in the model (Table 4).

Table.1 Tornqvist (TFP (T)) and Malmquist (TFP (M)) total factor productivity indices of jowar in Karnataka

\begin{tabular}{|c|c|c|c|}
\hline Year & TOI & TII & TFP(T) \\
\hline $\mathbf{1 9 7 1 - 1 9 8 4}$ & 1.173 & 0.999 & 1.178 \\
\hline $\mathbf{1 9 8 5 - 1 9 9 4}$ & 1.319 & 1.002 & 1.320 \\
\hline $\mathbf{1 9 9 5 - 2 0 0 4}$ & 1.078 & 1.103 & 0.976 \\
\hline $\mathbf{2 0 0 5 - 2 0 1 5}$ & 1.346 & 1.057 & 1.272 \\
\hline Average (1971-2015) & 1.227 & 1.037 & 1.188 \\
\hline CAGR (\%) & 0.352 & $0.281^{* *}$ & 0.070 \\
\hline
\end{tabular}

TOI $=$ Total output index, TII $=$ Total input index, TFP $=$ Total factor productivity

CAGR $=$ Compound annual growth rate

Table.2 Determinants of TFP growth of jowar in Karnataka

\begin{tabular}{|l|c|c|c|}
\hline \multicolumn{1}{|c|}{ Variable } & $\begin{array}{c}\text { Regression } \\
\text { coefficient }\end{array}$ & $\begin{array}{c}\text { Standard } \\
\text { error }\end{array}$ & t-ratio \\
\hline Constant & $-21.05^{* *}$ & 9.81 & -2.14 \\
\hline $\begin{array}{l}\text { Government expenditure } \\
\text { on Agricultural research } \\
\text { and Education (Rs.Ha) }\end{array}$ & 0.16 & 0.07 & 2.31 \\
\hline $\begin{array}{l}\text { Average rainfall(mm) } \\
\text { Ratio of nitrogen to } \\
\text { phosphorous fertilizers }\end{array}$ & $0.0072^{* * *}$ & 0.28 & 0.02 \\
\hline $\begin{array}{l}\text { Cropping intensity } \\
\text { Percent canal irrigated } \\
\text { area }\end{array}$ & $0.05 * *$ & 0.37 & -0.98 \\
\hline R 2 & 0.57 & & 2.37 \\
\hline D-W statistics & 2.51 & & \\
\hline
\end{tabular}

All variables are expressed in natural logarithms except those calculated as percentages

$*$ Significant at $1 \%$ level, ** Significant at 5\% level, *** Significant at $10 \%$ level 
Table.3 Tornqvist [TFP $(\mathrm{T})]$ total factor productivity of ragi in Karnataka

\begin{tabular}{|c|c|c|c|}
\hline Year & TOI & TII & TFP(T) \\
\hline $\mathbf{1 9 8 4 - 1 9 9 4}$ & 1.051 & 1.294 & 0.857 \\
\hline $\mathbf{1 9 9 5 - 2 0 0 4}$ & 0.944 & 1.307 & 0.775 \\
\hline $\mathbf{2 0 0 5 - 2 0 1 5}$ & 1.075 & 0.973 & 1.116 \\
\hline Average (1984-2015) & 1.026 & 1.188 & 0.921 \\
\hline CAGR (\%) & -0.095 & -1.277 & $1.197^{* *}$ \\
\hline
\end{tabular}

TOI $=$ Total output index, TII $=$ Total input index, TFP $=$ Total factor productivity CAGR $=$ Compound annual growth rate

Table.4 Determinants of TFP of ragi in Karnataka

\begin{tabular}{|l|c|c|c|}
\hline \multicolumn{1}{|c|}{ Variable } & $\begin{array}{c}\text { Regression } \\
\text { coeffi } \\
\text { cient }\end{array}$ & $\begin{array}{c}\text { Standard } \\
\text { error }\end{array}$ & t-ratio \\
\hline Constant & -12.982 & 12.675 & -1.024 \\
\hline $\begin{array}{l}\text { Government expenditure on } \\
\text { Agricultural research and } \\
\text { Education(Rs.Ha) }\end{array}$ & $0.166^{*}$ & 0.086 & 1.935 \\
\hline $\begin{array}{l}\text { Average rainfall(mm) } \\
\text { Ratio of nitrogen to } \\
\text { phosphorous fertilizers }\end{array}$ & -0.717 & 0.443 & -1.618 \\
\hline Cropping intensity & 3.946 & 0.352 & -1.726 \\
\hline R 2 & & 3.031 & 1.302 \\
\hline D-W statistics & & 0.690 & \\
\hline
\end{tabular}

*Significant at $1 \%$ level, ** Significant at 5\% level, ${ }^{* * *}$ Significant at $10 \%$ level

Figure.1 Tornqvist total factor productivity indices of jowar in Karnataka

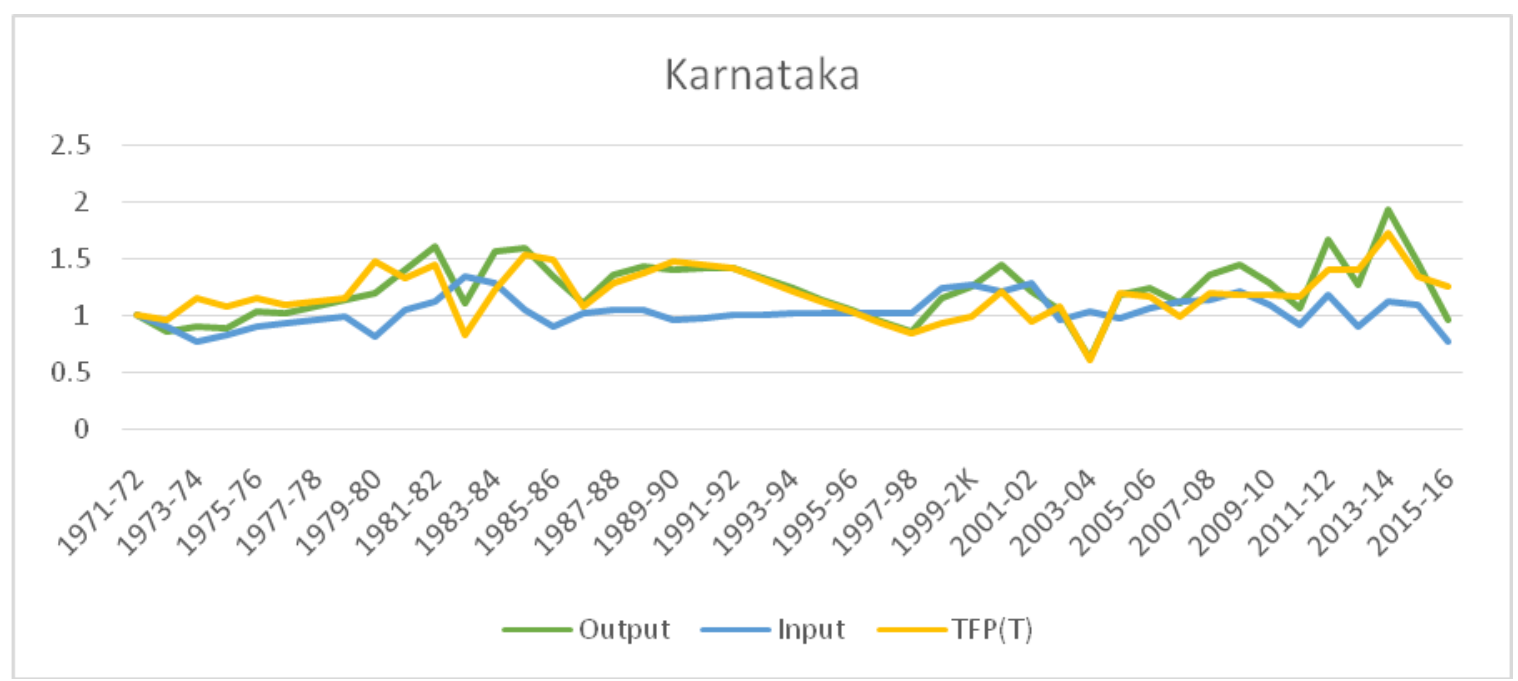


Figure.2 Tornqvist total factor productivity indices of ragi in Karnataka

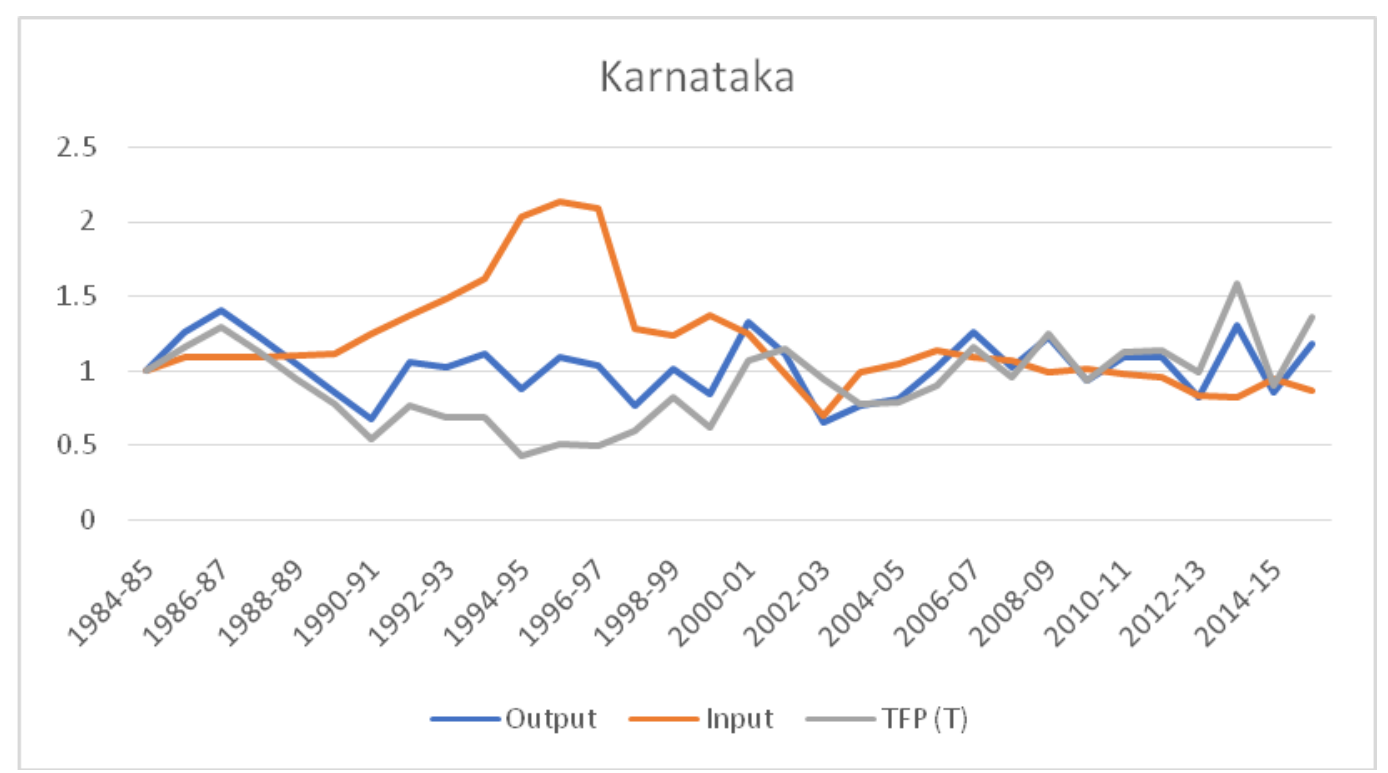

The improvement in total factor productivity was not due to crop inputs such as rainfall, road length, markets, better management practices, research and extension efforts, etc, of the state agricultural universities of Karnataka has released a number of new improved varieties to increase yield which are tolerant to drought. Hence, agricultural universities played a crucial role in the growth of total factor productivity of ragi crop.

In conclusion, this study has analyzed the TFP growth of two major widely cultivated major coarse cereals in Karnataka, viz. jowar and ragi from the 1970s to 2015. Since these two cereal crops are the staple diet of poor households in the dry regions and are the source of fodder for the livestock, increasing their productivity is important. Jowar and ragi are low-value crops and are cultivated in regions with traditional impediments like moisture-deficient soils. Hence, investments made in superior technologies for these crops become risky and uncertain. Demands for jowar and ragi are region- and economic class-specific, but there is evidence that demand for these cereal crops is rising partially for non-food purposes like poultry feed, industrial uses, etc. (Basavaraj et al., 2010). Therefore, to address the constraints involved in the cultivation of these two crops and to increase its potential for alternative uses, there is a need to raise their production through low-cost technologies.

\section{References}

Basavaraj, G., Parthasarathy, R.P., Bhagavatula, S. and Ahmed, W., 2010, Availability and utilization of pearl millet in India. SAT eJournal. 8:1-6

Chand, R, Kumar, P and Kumar, S. 2012. Total factor productivity and returns to public investment on agricultural research in India. Agricultural Economics Research Review. 25(2): 181-194.

Coelli, T.J. et al., 2005. An Introduction to Efficiency and Productivity Analysis. New York, United States: Springer.

Kannan, E. 2011. Total Factor Productivity Growth and Its Determinants in Karnataka Agriculture. Working paper 265. The Institute for Social and Economic Change. Bangalore.

Suresh, A. 2013. Technical change and 
efficiency of rice production in India: a Malmquist total factor productivity approach. Agricultural Economics
Research Review. 26 (Conference): 109-118.

\section{How to cite this article:}

Dinesh, T.M., K. Suhasini, B. Dayakar Rao, I.S. Rao and Srinivasa Chary, D. 2019. Estimation of Determinants of Total Factor Productivity of Millets in Karnataka: An Application of Parametric Approach. Int.J.Curr.Microbiol.App.Sci. 8(07): 1990-1997.

doi: https://doi.org/10.20546/ijcmas.2019.807.237 